\title{
Increasing Guidance and Counseling Teacher Capacity in Disaster Preparedness through Psychosocial Training
}

\author{
Irvan B. Handaka ${ }^{1}$, Wahyu N. E. Saputra ${ }^{2 *}$, Zela Septikasari ${ }^{3}$, Siti Muyana ${ }^{4}$, Muya Barida ${ }^{5}$, \\ Amien Wahyudi ${ }^{6}$, Agungbudiprabowo ${ }^{7}$, Dian A. Widyastuti ${ }^{8}$, Amirul lkhsan ${ }^{9}$, Ficky A. Kurniawan ${ }^{10}$ \\ 1,2,4-9 Universitas Ahmad Dahlan, Jalan Kolektor Ring Road Selatan, Tamanan Banguntapan Bantul Yogyakarta, Indonesia, \\ ${ }^{3}$ Universitas Negeri Yogyakarta, Jl. Colombo Yogyakarta No.1, Karang Malang, Caturtunggal, Depok, Sleman Yogyakarta, Indonesia, \\ ${ }^{10}$ UPN VETERAN Yogyakarta, Jl. SWK Jl. Ring Road Utara No.104, Ngropoh, Condongcatur, Depok, Sleman, Yogyakarta, Indonesia
}

\begin{abstract}
The Psychosocial Training was held in July 2021 and involved 17 Guidance and Counseling Teachers from 12 Muhammadiyah Junior High Schools in Yogyakarta City. The aims of this research are (1) to know the implementation of Psychosocial Support Services training, (2) Obstacles in the implementation of Psychosocial Support Services training, and (3) Knowing the benefits of Psychosocial Support Services training. This study is a piece of qualitative research, which aims to describe and analyses the social phenomenon of psychosocial training for guidance and counseling teacher in Junior High School in Yogyakarta City. Primary subjects in this study were 20 participants of psychosocial training and facilitator of training. Data collection was done by in-depth interview, observation, and documentation. The data analysis procedure in this research is (1) data reduction, (2) data presentation, and (3) conclusion. Data validity is done by triangulation of source and method triangulation. The training is carried out in three stages: pre-training stage is conducting a preliminary survey to see conditions in the field and planning activities to be carried out, training stage is the implementation of Psychosocial training, and evaluation stage of the results that have been achieved by the training participants are carried out. Obstacles in implementing psychosocial training include: training cannot be carried out optimally because the training is carried out online, limited time for training, some teachers are not active in psychosocial training because the media at zoom meetings is very limited. The facilitator maximizes training with WhatsApp Groups and the google document application on assignment. increasing the knowledge of participants after attending the training by increasing the post-test scores. Cooperation of various parties with school residents is needed so that psychosocial preparedness can be applied to pre-disaster, emergency response, and post-disaster.
\end{abstract}

Keywords: Psychosocial; Preparedness; Disaster; Training; Teacher.

\section{INTRODUCTION}

Indonesia is a country that has a high disaster risk. The territory of Indonesia, which is a disaster-prone area, especially geological natural disasters, is geographically located at the confluence of 3 (three) world tectonic plates, namely the Indian-Australian Plate in the south, the Eurasian Plate in the west, and the Pacific Plate in the east. The plate boundaries are a series of world volcanoes, which encircle the Pacific Ocean called the Pacific Ring of Fire. The series then met with the Mediterranean series and then formed volcanoes in Sumatra, Java, and Nusa Tenggara (BNPB, 2017). This is evidenced by the high impact on natural disasters and socio-economic vulnerability (Djalante \& Garschagen, 2017) \ngiven its high exposure to natural hazards coupled with its high $\backslash$ nsocioeconomic vulnerability. The aim of this chapter is to reviewl ndisaster events and impacts, and assess effectiveness of risk governancelnin responding to disasters and reducing risk. It discusses institutional $\backslash$ nand social-economic changes that have happened in response to particular|ndisasters, and how different social political changes influence disaster $\backslash n$ risk governance. There are extensive studies that have examined the Inprogress in building resilience in Indonesia, but studies that link\ndisaster events and key historical institutional responses over the Inperiod between 1900 and 2015 have not yet been done systematically.|nLearning from these can help to achieve more effective disaster risk $\backslash$ nreduction (DRR).

Law Number 24 of 2007 concerning Disaster Management explains that a disaster is an event or series of events that threatens and disrupts people's lives and livelihoods caused, both by natural factors and/or non-natural factors as well as human factors, resulting in human casualties, environmental damage, property loss, and psychological impact. The impact of

Corresponding Author e-mail: wahyu.saputra@bk.uad.ac.id https://orcid.org/0000-0001-8724-948X

How to cite this article: Handaka IB, Saputra WNE, Septikasari Z, Muyana S, Barida M, Wahyudi A, Agungbudiprabowo, Widyastuti DA, Ikhsan A, Kurniawan FA (2022). Increasing Guidance and Counseling Teacher Capacity in Disaster Preparedness through Psychosocial Training. Pegem Journal of Education and Instruction, Vol. 12, No. 1, 2022, 242-248

Source of support: Nil

Conflict of interest: None.

DOI: $10.47750 /$ pegegog.12.01.25

Received: 29.08 .2021

Accepted: 12.12.2021 Publication: 01.01.2022 
the disaster is not only loss of life and loss of property, but also psychological impact. Disaster impacts physical, psychological, social, and economic aspects of the individual, family, and the community. The impact of the disaster on children of different age groups is many times greater than that of adults (Elangovan \& Kasi, 2014). After a disaster, children's mental health needs range from support utilizing psychological first aid to psycho-education. The skills for psychological recovery, trauma-focused cognitive behavioral therapy, and cognitivebehavioral intervention for trauma school will also be needed when children and adolescents keep suffering from various psychiatric symptoms such as insomnia, anxiety, depressive mood, re-experience, and so on (Chang et al., 2015).

The Special Region of Yogyakarta is one of the provinces that has quite a lot of potential disaster threats, from the results of the risk assessment the City of Yogyakarta has potential threats including earthquakes, floods, landslides, volcanic eruptions, extreme weather, epidemics and disease outbreaks (BPBD Yogyakarta City, 2015). This condition is generally a natural phenomenon that cannot be predicted quickly and precisely, such as an earthquake for which until now there is no tool capable of detecting when an earthquake occurs and in March 2020 the Covid-19 pandemic hit the whole world, causing teaching and learning activities to be diverted. online or online.

Disasters have an impact on students, the school system, and affect children's basic rights, namely the right to education. The results of development in the field of education are inversely proportional to the damage to school facilities, prolonged disruption of education, limited access to schools, and declining quality of education (Selby \& Kagawa, 2012)302 hazards resulted in disasters that claimed almost 30,000 lives, affected 206 million people and inicted damages worth an estimated US\$366 billion, according to the United Nations Office for Disaster Risk Reduction ('UNISDR' Towards a Post2015 Framework for Disaster Risk Reduction. Disasters can also cause psychosocial impacts for school residents, while capacity building related to psychosocial is still very limited. Guidance and Counseling teachers can be an alternative whose capacity for psychosocial development can be increased, so that teachers have psychosocial knowledge and skills that must be applied during pre-disaster, emergency response and post-disaster.

The Institute for Research and Community Service (LPPM) of Ahmad Dahlan University Yogyakarta conducted training on Psychosocial Support Services (LDP) for Guidance and Counseling Teachers. Training on Psychosocial Support Services (LDP) for Guidance and Counseling teachers throughout the city of Yogyakarta held in July 2021. Psychosocial Support Services (LDP) training is very much needed in crisis counseling both during pre-disaster, during emergency response and post-disaster. This refers to the
Regulation of the Minister of National Education number 27 of 2008 concerning Standards of academic qualifications and competence of Indonesian counselors, counselors must have professional competence to master the practice of counseling services in various fields of individual life.

Development of psychosocial disaster preparedness program and its integration with existing policies, programs and services would help children to be psychosocially prepared as well as make the school system more effective in dealing with the psychosocial issues of children during disasters (Elangovan \& Kasi, 2014). Evaluation and consideration of the developmental needs of children and adolescents, as well as the needs of parents, families, and schools is also important. Domestic standardization of intervention and psychotherapeutic treatment should be performed for more effective interventions for a disaster (Chang et al., 2015).

Psychosocial Support Services (LDP) training makes Guidance and Counseling Teachers have superior competencies related to Psychosocial Support Services (LDP) materials. This is to answer the needs of the community, professional competence of counselors is required to be able to provide services in times of crisis or disaster situations. For this reason, psychosocial support service training is needed for Guidance and Counseling teachers at Muhammadiyah Junior High Schools in Yogyakarta City. Based on the introduction that has been described above, it can formulate the problem in this research is: (1) How is the implementation of Psychosocial Support Services (LDP)? (2) What are the obstacles that occur in Psychosocial Support Services (LDP)? (3) What are the benefits of Psychosocial Support Services (LDP) training?

\section{Method}

\section{Research Design}

This study is a piece of qualitative research, which aims to describe and analyses social phenomenon of psychosocial training for guidance and counselling teacher Junior High School in Yogyakarta City.

\section{Participants}

The primary subjects in this study were 20 participants of psychosocial training and facilitator of training. They are selected for this activity, they are teachers who need training and reinforcement on psychosocial training and facilitators of training. Moreover, schools in Yogyakarta are schools located in disaster-prone areas.

\section{Data Collection Tools}

Data collection was done by in-depth interview, observation, and documentation. In-depth interviewing is the process of obtaining information for research purposes by means of face-to-face questions and answers between the interviewer 
and the respondent or the person being interviewed, with or without using interview guidelines in which the interviewer and informant are involved in a relatively long social life. Observation is used in this study to obtain important information about people, because what is said is not necessarily in accordance with what is done. While documentation is used to provide documents using accurate evidence from recording specific sources of information from essays / writings, wills, books, laws, and so on.

\section{Data Analysis}

The data analysis procedure in this research is (1) data reduction, (2) data presentation, and (3) conclusion. Data validity is done by triangulation of source and method triangulation.

\section{FINDINGS}

Psychosocial training for Guidance and Counseling teachers is carried out through several stages, namely Pre-Training Stage, Training Stage, and Evaluation Stage. The following is an explanation of the stages of psychosocial training.

\section{Pre-Training Stage}

The first stage is conducting a preliminary survey to see conditions in the field and planning activities to be carried out. The planning process includes identification/needs assessment, identification of potential/threats of disasters and existing weaknesses, determining agreement on activities to be carried out, and organizing activities.

\section{Training Stage}

The second stage is the implementation of activities. The activities carried out consisted of several stages including the first pre-test then material on psychosocial understanding, psychosocial legal basis, psychosocial impact after disaster and psychosocial welfare and psychosocial intervention pyramid, understanding psychosocial support services, stages of psychosocial support services, assessment of psychosocial support services, an example of a case study of psychosocial support services in Central Sulawesi after the 2018 earthquake and tsunami, and finally the post-test. Participants are representatives of Guidance and Counseling teachers at Muhammadiyah Junior High School in Yogyakarta City. The service team and experts will act as facilitators. Based on data from the Muhammadiyah Regional Leadership (PDM) of Yogyakarta City, there are 12 Muhammadiyah junior high schools in Yogyakarta City with details as shown in the Table 1:

The psychosocial training was carried out in July 2021. This activity was carried out online using the zoom meeting application to minimize the risk of Covid 19. There were 17 training participants and 3 facilitators.

Table. 2 shows the details of the Psychosocial Support Services training curriculum. The research team introduced the overall psychosocial training objectives and conducted a pre-test to all participants. The first material presented is psychosocial understanding. The facilitator explains psychosocial understanding, then combines it with psychosocial examples so that participants can understand psychosocial understanding well. An explanation of the notion of psychosocial becomes the basis for the next material. The second material is about the basis of psychosocial law. The facilitator explains the legal basis for psychosocial implementation in accordance with the laws and regulations in Indonesia. The facilitator also explains the post-disaster psychosocial impact. The facilitator divides the participants into five groups. Each group discusses psychosocial effects which include physiological effects, feelings, thoughts, behavior, and social relationships. Then each group presented the results of the discussion.

Table 1: Data for Muhammadiyah Junior High School in Yogyakarta City

\begin{tabular}{llll}
\hline No & School Name & Address & Telephone \\
\hline 1 & SMP Muhammadiyah 1 & Purwodiningratan NG I/902-B & 589624 \\
2 & SMP Muhammadiyah 2 & Jl. Kapas II No. 7 & 564136 \\
3 & SMP Muhammadiyah 3 & Jl. Kapt. Tendean 19 & 375158 \\
4 & SMP Muhammadiyah 4 & Jl. Ki Mangunsarkoro No. 43 & 554623 \\
5 & SMP Muhammadiyah 5 & Jl. Patehan Lor 25 & 373211 \\
6 & SMP Muhammadiyah 6 & Jl. KH. Wakhid Hasyim 107 & 374720 \\
7 & SMP Muhammadiyah 7 & Purbayan Kotagede & 373190 \\
8 & SMP Muhammadiyah 8 & Jl. Kenari 11 Miliran & 585446 \\
9 & SMP Muhammadiyah 9 & Karangkajen MG III/1039 & 370169 \\
10 & SMP Muhammadiyah 10 & Jl. Kartini GK I/49-A & 560412 \\
11 & Madrasah Muallimin & Jl. Letjen S.Parman No.68, Wirobrajan & 373122 \\
12 & Madrasah Muallimat & Jl. Suronatan No.653, Notoprajan & 374687 \\
\hline
\end{tabular}


Table 2: Curriculum Details

\begin{tabular}{ll}
\hline No & Curriculum Material \\
\hline 1 & Psychosocial understanding \\
2 & Psychosocial legal basis \\
3 & Psychosocial impact after disaster and social welfare \\
4 & Psychosocial well-being and the pyramid of psychosocial interventions \\
5 & Definition of psychosocial support services \\
6 & Stages of psychosocial support services \\
7 & Assessment of psychosocial support services \\
8 & Example of a case study of psychosocial support services in Central Sulawesi after the 2018 earthquake and tsunami \\
9 & Individual and group assignments \\
\hline
\end{tabular}

The facilitator also delivered material on psychosocial welfare and psychosocial intervention pyramids, understanding psychosocial support services, stages of psychosocial support services, assessment of psychosocial support services, examples of case studies of psychosocial support services in Central Sulawesi after the 2018 earthquake and tsunami. The facilitator divided participants into five groups. Each group is given the task of designing a psychosocial support service program according to cases that occurred in schools during the Covid 19 Pandemic. Each group is expected to be able to produce programs/outcomes that are different from one another so that they can be implemented to be applied during disaster response. At the end of the activity, all participants were given a post-test.

\section{Evaluation Stage}

The last stage is the evaluation stage. At this stage an evaluation of the results that have been achieved by the training participants is carried out. Further feedback and improvements can be made at this stage. Evaluation is given by collecting data obtained from psychosocial training activities.

Based on the results of data processing carried out by researchers on understanding psychosocial support services for Guidance and Counseling teachers at Muhamamdiyah Junior High Shools Yogyakarta City, it was found that before training participants filled out a pre-test to measure the extent to which participants understood psychosocial support services and obtained an average score. from Guidance and Counseling Teachers of 73.82. After the psychosocial support service training and post-test were conducted, the average score increased to 77.06. The increasing knowledge of Guidance and Counseling teachers regarding psychosocial support services is influenced by interactive techniques, media, and methods designed by the facilitator during the training. The scores or test results can be seen in Figure 1 and Figure 2..

Obstacles in implementing psychosocial training include: (1) Training cannot be carried out optimally because the training is carried out online, (2) Limited time for training, (3)

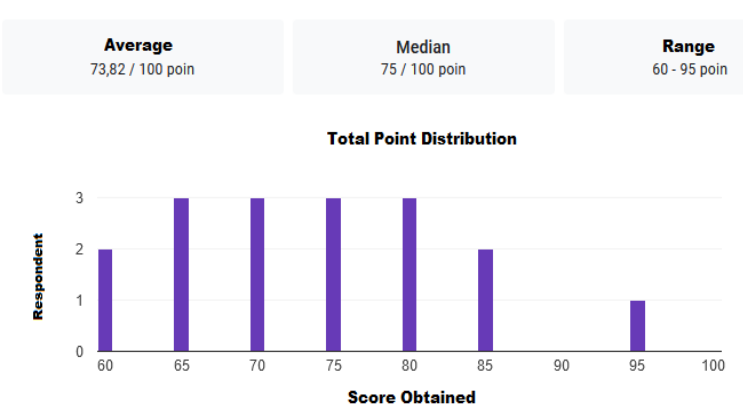

Fig. 1: Pre Test Results

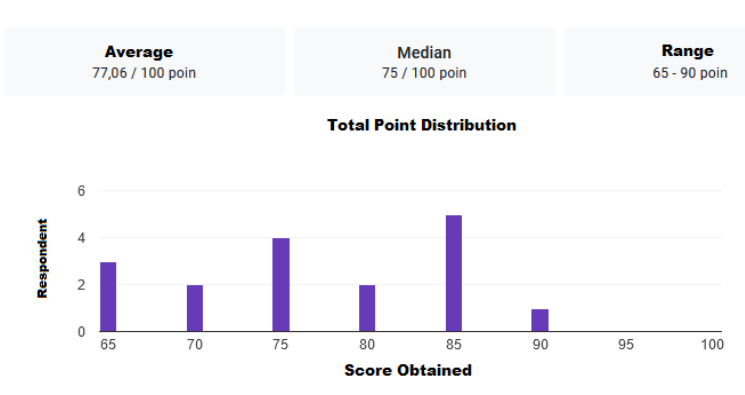

Fig. 2: Post Test Results

Some teachers are not active in psychosocial training because the media at zoom meetings is very limited. To maximize the training, the facilitator further guides the participants in the WhatsApp Group and assignments are carried out through the google document application so that teachers can easily access them directly.

\section{Discussion}

The nation of Indonesia is in an area of geological instability, resulting in repeated and severe natural disasters including earthquakes, volcanic eruptions, and tsunamis. Teachers, as adult authority figures and people with whom students spend a majority of their day, can play a major role in the lives of children in a disaster-prone community. The impact of this intervention on reducing teacher distress and on 
improving student behavior and school performance over time. Analyses revealed a significant relationship between teachers' depression and self-reported negative classroom behavior, a significant relationship between teachers' posttraumatic distress and general beliefs about teacher efficacy, and a significant drop in depression and posttraumatic stress symptoms from before to after the intervention (Seyle et al., 2013). Children are among the most vulnerable groups during and after a natural disaster experiencing a range of stressors such as fear of death or loss of a loved one, the loss of a home and community, displacement to a strange neighborhood or school, and even separation from their family. Psychosocial support helped children: articulate their feelings, process grief, regulate emotions such as anger and aggression, and gain knowledge on how to handle bullying behaviors in their school. This article builds on the literature supporting postdisaster psychosocial school-based interventions (Powell \& Holleran-Steiker, 2017). Teachers have an important role in disaster preparedness, especially in relation to the psychosocial preparedness of school residents. Psychosocial is not only implemented when a disaster occurs, but must be better prepared before a disaster occurs. One of the psychosocial preparedness efforts can be carried out with psychosocial training for school residents, so that school residents have a good understanding of psychosocial knowledge and can play a direct role in psychosocial support services during emergency and post-disaster responses.

Any impact of disaster can be looked at in two ways: firstly by ascertaining the characteristics of the event itself, and secondly, how that event is appraised by those affected. Depending on different phases of the impact of the disaster, individuals will respond in different styles. Psychosocial interventions must be tailored to address the needs of the target population, with special attention paid to vulnerable groups such as children, women and the elderly. These should also be modulated according to the phase of recovery following the event occurrence because each phase will highlight different needs. The four phases of intervention, although determined separately, may show an overlap. In the initial phases, the emphasis is on social intervention that can be delivered by community-level workers. In the later phases, the psychological issues that emerge necessitate the services of trained professionals. Initial social care will need to give way to psychological care, and on occasion both will need to be combined for a considerable period. Since psychosocial care is a long-term, continuous process, disaster management and preparedness programmes must invest in training for capacity building by training community workers and primary care health professionals (K., 2006).

General principles of psychosocial disaster intervention: (1) Assessment of disaster, extant service systems and incoming resources. (2) Assessment of help-seeking pathways and cultural models of illness. (3) Facilitation and support for family reunion, identification of the dead and cultural and religious practices to address death and grief. (4) Foster and bolster community group activities where possible. (5) Psychosocial training of community, aid and health workers using a train the trainer model to promote case identification, psychoeducation and intervention, with specific emphasis on vulnerable groups, especially children. (6) Promote general community psychoeducation. (7) Train medical and health staff in basic psychiatric and psychological assessment and intervention for post-traumatic stress, mood and anxiety disorders. (8) Minimize risk factors for psychiatric morbidity such as displacement and loss of gainful activity. (9) Reshape mental health systems recognizing the long-term psychiatric sequelae of disaster (Sundram et al., 2008).

Psychosocial disaster preparedness, through teachers, is one among the best ways to prepare children to face the psychosocial consequences of disasters. teachers who were provided training on psychosocial disaster preparedness had better knowledge than the control group. Development of psychosocial disaster preparedness program and its integration with existing policies, programs and services would help children to be psychosocially prepared as well as make the school system more effective in dealing with the psychosocial issues of children during disasters (Elangovan \& Kasi, 2014). This is in accordance with the benefits of psychosocial training. The benefits of psychosocial training for teachers include (1) increasing teacher knowledge and skills in Psychosocial Support Services, (2) Teachers knowing in more detail about the psychosocial impacts caused by disasters in accordance with the context of disasters that occur in schools, (3) Teachers understanding properly the psychosocial intervention pyramid and ensure that teachers are at which level in the psychosocial intervention pyramid, (4) teachers know the stages of psychosocial support services and apply the stages in case studies that occur in schools, (5) teachers can design psychosocial assessments, and (6) Teachers can intervene in psychosocial support services in the school environment.

Relationship among agencies associated with a disaster, training professionals and prepared programs for disaster will be needed in pre-disaster stage. After a disaster, children's mental health needs range from support utilizing psychological first aid to psycho-education. The skills for psychological recovery, trauma focused cognitive behavioral therapy, and cognitive behavioral intervention for trauma school will also be needed when children and adolescents keep suffering from various psychiatric symptoms such as insomnia, anxiety, depressive mood, re-experience, and so on. Evaluation and consideration of the developmental needs of children and adolescents, as well as the needs of parents, families, and schools is also important. Domestic standardization of intervention and psychotherapeutic treatment should be 
performed for more effective interventions for a disaster (Chang et al., 2015). Successful disaster psychosocial planning and the institutionalizing of psychosocial response within emergency management require clearly-defined skill sets. This necessitates anticipating both the short- and long-term psychosocial implications of a disaster or health emergency (ie, pandemic) by developing effective and sustained working relationships among psychosocial providers, programs, and other planning partners (Cox \& Danford, 2014). Inter-institutional cooperation is very much needed in the implementation of psychosocial support services in schools. Inter-institutional collaboration is carried out to ensure that psychosocial knowledge does not only exist in the emergency response phase. Schools can collaborate with BNPB, BPBD, Social Service, Village Disaster Risk Reduction Forum, and NGOs in the pre-disaster, emergency response, and postdisaster phases.

Development and implementation an assessment and intervention program that can be used as psychosocial first aid for children caught up in a humanitarian emergency. Because this disaster was not anticipated, we were fortunate to have a group of previously trained individuals who were able to implement the knowledge and skills required to do workforce training. More communities and countries need to do more disaster preparation that includes psychosocial first aid for children. It is important that multiple modalities of psychosocial assistance be used and available to strengthen families, to restore livelihoods, and to revitalize communities in the aftermath of a disaster (Pairojkul et al., 2010). Any response to the mental health needs of the affected community following any disaster depends upon a number of factors, including disaster preparedness, existence of mental health services, resources in human and financial terms, along with the magnitude, cause and suddenness of the event (Vijaykumar et al., 2006). This is the reason that psychosocial activities must be carried out in the pre-disaster, emergency response, and post-disaster phases.

\section{Conclusion}

Psychosocial support service training was carried out during July 2021 by the Guidance and Counseling Study program at Ahmad Dahlan University (UAD). This psychosocial training involved 17 Guidance and Counseling Teachers from 12 Muhammadiyah Middle Schools in Yogyakarta City. The facilitator provides interactive material so that participants become active and enthusiastic about participating in the activity. Obstacles in implementing psychosocial training include: (1) Training cannot be carried out optimally because the training is carried out online, (2) Limited time for training, (3) Some teachers are not active in psychosocial training because the media at zoom meetings is very limited. To maximize the training, the facilitator further guides the participants in the WhatsApp Group and assignments are carried out through the google document application so that teachers can easily access them directly. This is in accordance with the benefits of psychosocial training. The benefits of psychosocial training for teachers include (1) increasing teacher knowledge and skills in Psychosocial Support Services, (2) Teachers knowing in more detail about the psychosocial impacts caused by disasters in accordance with the context of disasters that occur in schools, (3) Teachers understanding properly the psychosocial intervention pyramid and ensure that teachers are at which level in the psychosocial intervention pyramid, (4) teachers know the stages of psychosocial support services and apply the stages in case studies that occur in schools, (5) teachers can design psychosocial assessments, and (6) Teachers can intervene in psychosocial support services in the school environment. The increase in knowledge is evidenced by the results of the pretest and posttest which have increased scores, previously the pretest score was 73.82 after the training was carried out the post test score became 77.06 .

\section{SUgGestion}

Suggestions for improving psychosocial training in the future are expected that the training time is adjusted to the material so that psychosocial knowledge and skills can be conveyed properly. Psychosocial support service training activities can be carried out offline and with the support of activity facilities and infrastructure.

\section{References}

BNPB. (2017). Potensi dan Ancaman Bencana. https://www.bnpb. go.id/home/potensi. Accessed On 20 July 2021.

BPBD Kota Yogyakarta. (2014). Peta Kawasan Rawwan Bencana Kota Yogyakarta, https://bpbd.jogjakota.go.id/page/index/petakawasan-rawan-bencana. Diakses Pada Tanggal 20 Juli 2021.

Chang, H. Y., Lee, C.-S., Park, J., Bhang, S. Y., \& Seo, J.-Y. (2015). Psychosocial Intervention and Practical Experience in Children and Adolescent before and after a Disaster. Journal of Korean Neuropsychiatric Association, 54(3), 276. https://doi. org/10.4306/jknpa.2015.54.3.276

Cox, R. S., \& Danford, T. (2014). The Need for a Systematic Approach to Disaster Psychosocial Response: A Suggested Competency Framework. Prehospital and Disaster Medicine, 29(02), 183-189. https://doi.org/10.1017/s1049023x14000259

Djalante, R., \& Garschagen, M. (2017). A review of disaster trend and disaster risk governance in Indonesia: 1900-2015. In R. Djalante, M. Garschagen, F. Thomalla, \& R. Shaw (Eds.), Disaster risk reduction in Indonesia (pp. 21-56). Springer.

Elangovan, A. R., \& Kasi, S. (2014b). Psychosocial disaster preparedness for school children by teachers. International Journal of Disaster Risk Reduction, 12, 119-124. https://doi. org/10.1016/j.ijdrr.2014.12.007

Rao, K. (2006). Psychosocial support in disaster-affected communities. International Review of Psychiatry, 18(6), 501505. https://doi.org/10.1080/09540260601038472 
Peraturan Menteri Pendidikan Nasional nomor 27 tahun 2008 Tentang Standar Kualifikasi Akademik dan Kompotensi Konselor.

Powell, T., \& Holleran-Steiker, L. K. (2017). Supporting children after a disaster: A case study of a psychosocial school-based intervention. Clinical Social Work Journal, 45(2), 176-188. https://doi.org/10.1007/s10615-015-0557-y

Pairojkul, S., Siripul, P., Prateepchaikul, L., Kusol, K., \& Puytrakul, T. (2010). Psychosocial first aid: support for the child survivors of the Asian tsunami. Journal of Developmental \& Behavioral Pediatrics, 31(9), 723-727. https://doi.org/10.1097/ DBP.0b013e3181f46de2

Selby, D., \& Kagawa, F. (2012). Disaster risk reduction in school curricula: case studies from thirty countries. In Disaster risk reduction in school curricula: case studies from thirty countries. http://www.unicef.org/education/files/DRRinCurriculaMapping30countriesFINAL.pdf
Seyle, D. C., Widyatmoko, C. S., \& Silver, R. C. (2013). Coping with natural disasters in Yogyakarta, Indonesia: A study of elementary school teachers. School Psychology International, 34(4), 387-404. https://doi.org/10.1177/0143034312446889

Sundram, S., Karim, M. E., Ladrido-Ignacio, L., Maramis, A., Mufti, K. A., Nagaraja, D., Shinfuku, N., Somasundaram, D., Udomratn, P., Yizhuang, Z., Ahsan, A., Chaudhry, H. R., Chowdhury, S., D’Souza, R., Dongfeng, Z., Firoz, A. H. M., Hamid, M. A., Indradjaya, S., Math, S. B., .. Wahab, M. A. (2008). Psychosocial responses to disaster: An Asian perspective. Asian Journal of Psychiatry, 1(1), 7-14. https://doi.org/10.1016/j.ajp.2008.07.004

Undang-undang Nomor 24 Tahun 2007 Tentang Penanggulangan Bencana.

Vijaykumar, L., Thara, R., John, S., \& Chellappa, S. (2006). Psychosocial interventions after tsunami in Tamil Nadu, India. International Review of Psychiatry, 18(3), 225-231. https://doi. org/10.1080/0954026060065591 